\title{
Acquired hemophilia A as a cause of recurrent bleeding into the pleural cavity - case report and literature review
}

\author{
maveran w w \\ ${ }^{1}$ Department of Thoracic Surgery and Transplantation, Pomeranian Medical University in Szczecin, Poland \\ 2Department of Internal Medicine, Health Care Centre "Zdroje" in Szczecin, Poland
}



Kardiochirurgia i Torakochirurgia Polska 2014; 11 (3): 329-335

\begin{abstract}
Acquired hemophilia $A$ is a coagulation disorder caused by autoantibodies against blood coagulation factor VIII. The first sign of this disease is often massive bleeding, which can affect patients after routine procedures. The parameter which indicates the presence of this condition is isolated prolonged activated partial thromboplastin time (APTT). The present article describes a case of a 32-year-old man with acute interstitial pneumonia and pleural effusion, in whom a massive hemothorax appeared after thoracocentesis; active bleeding was observed after the introduction of a chest tube. The patient was operated on, and no pinpoint bleeding was discovered during the procedure. Active bleeding was still taking place postoperatively. The patient underwent another operation after 6 days. Once more, no pinpoint bleeding was found. Prolonged APTT was observed. The activity of blood coagulation factor VIII was $3.04 \%$. The presence of antibodies against factor VIII was confirmed, and acquired hemophilia was diagnosed. The article also includes an analysis of the literature on acquired hemophilia.
\end{abstract}

Key words: acquired hemophilia A, hemothorax.

\section{Introduction}

Acquired hemophilia is a severe bleeding diathesis occurring with the incidence of approx. 1 case per 1 million individuals per year. It is equally common in both sexes and usually appears at old age. This potentially fatal disorder is caused by the activity of autoantibodies impairing the function of blood coagulation factors, mainly factor VIII (acquired hemophilia A) [1-3]. In approx. 50\% of cases, it is idiopathic in nature. It may also be associated with autoimmune diseases (systemic lupus, rheumatoid arthritis, myasthenia, multiple sclerosis, non-specific inflammatory

\section{Streszczenie}

Hemofilia A nabyta to zaburzenie krzepnięcia wywołane autoprzeciwciałami skierowanymi przeciw czynnikowi VIII krzepnięcia. Jej pierwszym objawem jest często masywne krwawienie. Może ono wystąpić u chorych po drobnych, rutynowo wykonywanych zabiegach. Jedynym parametrem wskazującym na możliwość wystąpienia tej choroby jest zwykle izolowane wydłużenie czasu częściowej tromboplastyny po aktywacji (APTT). W pracy przedstawiono przypadek 32-letniego mężczyzny z ostrym śródmiąższowym zapaleniem płuc oraz płynem w jamie opłucnej. Po punkcji jamy opłucnej stwierdzono rozległy krwiak. Po wprowadzeniu drenu do jamy opłucnej obserwowano cechy czynnego krwawienia. Pacjenta zakwalifikowano do leczenia operacyjnego. Nie wykryto pojedynczego miejsca krwawienia. Po zabiegu nadal obserwowano cechy czynnego krwawienia do jamy opłucnej. Powtórnie operowano pacjenta w 6. dobie. Ponownie nie wykryto pojedynczego miejsca krwawienia. Obserwowano wydłużenie czasu APTT. Oznaczono poziom aktywności czynników krzepnięcia. Aktywność czynnika VIII była na poziomie 3,04\%. Potwierdzono jakościowo obecność przeciwciał przeciw czynnikowi VIII. Rozpoznano hemofilię A nabytą. W dalszej części pracy dokonano przeglądu piśmiennictwa dotyczącego hemofilii nabytej.

Słowa kluczowe: hemofilia A nabyta, krwiak jamy opłucnej.

bowel disease), cancer, dermatological diseases (psoriasis, pemphigus), infections (hepatitis $B$ and $C$ ), chronic respiratory diseases (asthma, COPD), or diabetes. About $10 \%$ of hemophilia cases are associated with pregnancy and the perinatal period $[2,4-8]$. The first sign of acquired hemophilia is usually sudden, massive, life-threatening bleeding occurring in a patient without previous coagulation disorders. The bleeding events may be spontaneous or follow a surgical procedure or injury [5]. They include hemorrhages into the hypodermis, digestive tract, genitourinary system, retroperitoneal space, as well as into the respiratory sys-

Address for correspondence: Małgorzata Wojtyś, Department of Thoracic Surgery and Transplantation PUM in Szczecin,

A. Sokołowskiego 11, 70-891 Szczecin-Zdunowo, phone: +48 889944 582, e-mail: margaretkaw@wp.pl 
tem and pleural cavity [1, 3]. Mortalities have been reported as early as in the first week after the occurrence of bleeding from the digestive tract and lungs. The mortalities that occurred later were associated with soft tissue, intracranial, and retroperitoneal bleeding $[1,4]$. The mortality rate caused by bleeding in patients with acquired hemophilia is approx. $9 \%$ for the last decade, while earlier reports estimated it at $22-31 \%[9,10]$. Without any treatment, the mortality rate has been reported at $41 \%$ [4]. Therefore, spreading the knowledge about this disease may further contribute to lowering the percentage of deaths. The characteristic features of acquired hemophilia include isolated prolonged APTT, low activity of the coagulation factor targeted by the antibodies, and the presence of antibody titer $[2,3,11]$. The present study discusses a case of a young man with recurrent, massive bleeding into the pleural cavity caused by acquired hemophilia $A$ and presents an analysis of literature devoted to acquired hemophilia.

\section{Case study}

The patient was a 32-year-old man with hypertension, who had smoked 20 cigarettes a day for 15 years. Four years earlier, he had undergone a partial gastrectomy due to a perforated pyloric ulcer with peritonitis and septic shock. He was treated at the pulmonary disease department, where acute interstitial pneumonitis was suspected on the basis of chest X-ray, chest computed tomography (CT), bronchofiberoscopy, abdominal cavity and heart ultrasonography, laboratory tests, and medical history (nicotinism, occupational exposure to wood dust and resins). After the implementation of steroid therapy, the patient was transferred to a center with a higher referral level. Cough, fever up to $39^{\circ} \mathrm{C}$, respiratory failure, and anemia occurred during hospitalization. Bronchial lavage revealed the presence of Candida albicans. Chest X-ray showed opacities in the lower and middle lung fields on the left side. Laboratory tests provided the following results: hemoglobin ( $\mathrm{Hgb}$ ) level $9.3 \mathrm{~g} / \mathrm{dl}$, hematocrit (Hct) $31.9 \%$, red blood cells (RBC) 3.30 $\times 10^{6} / \mu$ l, white blood cells $(\mathrm{WBC}) 17.75 \times 10^{3} / \mu$ l, platelets (PIt) $980 \times 10^{3} / \mu \mathrm{l}$ (Table I). Ultrasonography revealed the presence of fluid in the left pleural cavity; it was aspirated twice, yielding $1400 \mathrm{ml}$ and $150 \mathrm{ml}$ of bloody fluid. Several hours after the second aspiration, the patient's condition deteriorated rapidly. He experienced weakness, drenching sweats, blood pressure reduction to $80 / 40 \mathrm{mmHg}$, heart rate elevation to $120 / \mathrm{min}$, and hemoglobin level reduction to $6.5 \mathrm{~g} / \mathrm{dl}$. The signs of shock were associated with a rapidly growing hematoma in the left pleural cavity, which most likely appeared due to an intercostal artery injury sustained during the aspiration of the pleural cavity. Chest X-ray showed an opacity in the entire left lung field and mediastinal shift to the right side (Fig. 1). Drainage of the left pleural cavity was urgently performed, and the patient was transferred to the thoracic surgery department. Suction drainage of the left pleural cavity was continued; fluids, 4 units of packed red blood cells (PRBC), and plasma were administered intravenously. During the first 24 hours, $900 \mathrm{ml}$ of bloody content was drained. Blood pressure rose to $107 / 90 \mathrm{mmHg}$, while heart rate decreased to $98 / \mathrm{min}$. Laboratory tests revealed the following: $\mathrm{Hgb} 7.5 \mathrm{~g} / \mathrm{dl}$, Hct 24.6\%,

Tab. I. Laboratory test results from each stage of treatment

\begin{tabular}{|c|c|c|c|c|c|c|c|c|}
\hline Parameter & $\begin{array}{c}\mathrm{Hgb} \\
(\mathrm{mg} / \mathrm{dl})\end{array}$ & $\begin{array}{l}\text { Saturation } \\
(\%)\end{array}$ & $\begin{array}{l}\text { Quick's } \\
\text { Index (\%) }\end{array}$ & INR & PT (s.) & $\begin{array}{l}\text { APTT } \\
\text { (s.) }\end{array}$ & $\begin{array}{l}\text { Plt } \\
(\mathrm{G} / \mathrm{l})\end{array}$ & $\begin{array}{l}\text { Fibrinogen } \\
(\mathrm{g} / \mathrm{l})\end{array}$ \\
\hline Examination on admission & 9.3 & 84.2 & 64 & 1.53 & 18 & 45 & 980.0 & - \\
\hline $\begin{array}{l}\text { Examination several hours after } \\
\text { aspiration of the pleural cavity }\end{array}$ & 6.5 & 74.2 & 59 & 1.65 & 19 & 57 & - & 3.4 \\
\hline $\begin{array}{l}\text { First day after aspiration of the pleural } \\
\text { cavity }\end{array}$ & 7.5 & 89.4 & 47 & 2.06 & 24 & 77 & 469 & - \\
\hline Day "zero" after operation no. 1 & 7.9 & 99 & - & - & - & - & 250 & 1.2 \\
\hline First day after operation no. 1 & 8.6 & 98 & 64 & 1.52 & 17 & 58 & 311 & 3.6 \\
\hline Second day after operation no. 1 & 7.4 & 94 & - & - & - & - & 257 & - \\
\hline Third day after operation no. 1 & 8.5 & - & 84 & 1.19 & 13 & 68 & 318 & - \\
\hline Fourth day after operation no. 1 & 9.5 & - & - & - & - & - & 357 & - \\
\hline Fifth day after operation no. 1 & 8.4 & - & - & - & - & - & 498 & - \\
\hline Sixth day after operation no. 1 & 7.9 & - & - & - & - & - & 498 & - \\
\hline Day "zero" after operation no. 2 & 8.2 & 91.5 & 66 & 1.49 & 17 & 77 & 247 & 1.8 \\
\hline First day after operation no. 2 & 7.5 & 92.3 & 84 & 1.29 & 15 & 77 & 334 & 2.3 \\
\hline Second day after operation no. 2 & 9.6 & 88 & 98 & 1.02 & 11 & 83 & 317 & 3.9 \\
\hline Third day after operation no. 2 & 9.7 & 90 & 90 & 1.1 & 12 & 74 & 451 & 4.9 \\
\hline Fourth day after operation no. 2 & 10.3 & - & 90 & 1.1 & 12 & 78 & 676 & 3.7 \\
\hline
\end{tabular}

Hgb - hemoglobin, INR - international normalized ratio, PT - prothrombin time, APTT - activated partial thromboplastin time, Plt - platelets 
RBC $2.63 \times 10^{6} / \mu$ l, WBC $35.37 \times 10^{3} / \mu$ l, Plt $331 \times 10^{3} / \mu$ l, features of renal failure, hyperpotassemia, features of liver damage, unstable blood coagulation, and reduced levels of total protein and albumins. The opacity in the left lung field was still present in follow-up chest X-ray. Therefore, leftsided posterolateral thoracotomy was performed, during which approx. $2000 \mathrm{ml}$ of organized hematoma was evacuated, while the stiff and hepatized basal segments and the lingula of the left lung were resected. Thorough hemostasis was performed, and two drains were inserted into the left pleural cavity. No pinpoint bleeding was found. The patient was transferred directly from the operating theater to the intensive care unit, from where he was further moved to the thoracic surgery department after 2 days. The results of laboratory tests performed on the first postoperative day were as follows: Hgb $8.6 \mathrm{~g} / \mathrm{dl}$, Hct $25.9 \%$, RBC $3.07 \times 10^{6} / \mu \mathrm{l}$, WBC $20.38 \times 10^{3} / \mu$ l, Plt $311 \times 10^{3} / \mu \mathrm{l} ; 500 \mathrm{ml}$ of bloody content was evacuated through the drains. The patient received 2 units of PRBC and 2 units of fresh frozen plasma. During the second postoperative day, the patient's hemoglobin level dropped to $7.4 \mathrm{~g} / \mathrm{dl}$ (Hct 21.8\%, RBC $2.59 \times 10^{6} / \mu \mathrm{l}$, WBC $20.1 \times 10^{3} / \mu \mathrm{l}$, Plt $257 \times 10^{3} / \mu \mathrm{l}$ ); the drainage of bloody content from the pleural cavity increased in volume $(800 \mathrm{ml}$ $+150 \mathrm{ml}$ ). In light of this, 2 units of PRBC and 3 units of plasma were transfused. On the third postoperative day, the drained volume was $600 \mathrm{ml}+150 \mathrm{ml}$; laboratory test results were as follows: Hgb $8.5 \mathrm{~g} \%$, Hct $25.8 \%$, RBC 2.99 $\times 10^{6} / \mu \mathrm{l}$, WBC $20.12 \times 10^{3} / \mu \mathrm{l}$, Plt $318 \times 10^{3} / \mu \mathrm{l}$. During the next 2 days, the amount of drained content dropped to 100 $\mathrm{ml}+250 \mathrm{ml}$ and $50 \mathrm{ml}+50 \mathrm{ml}$, respectively, while the level of hemoglobin increased. On the $6^{\text {th }}$ postoperative day, the amount of drained fluid increased once again to $200 \mathrm{ml}$ $+50 \mathrm{ml}$, and the level of hemoglobin dropped to $7.9 \mathrm{~g} / \mathrm{dl}$ (Hct 25.3\%, RBC $2.8 \times 10^{6} / \mu$ l, WBC $31.55 \times 10^{3} / \mu$ l, Plt $498 \times$ $10^{3} / \mu \mathrm{l}$ ). Chest $\mathrm{X}$-ray revealed a massive opacity in the lower

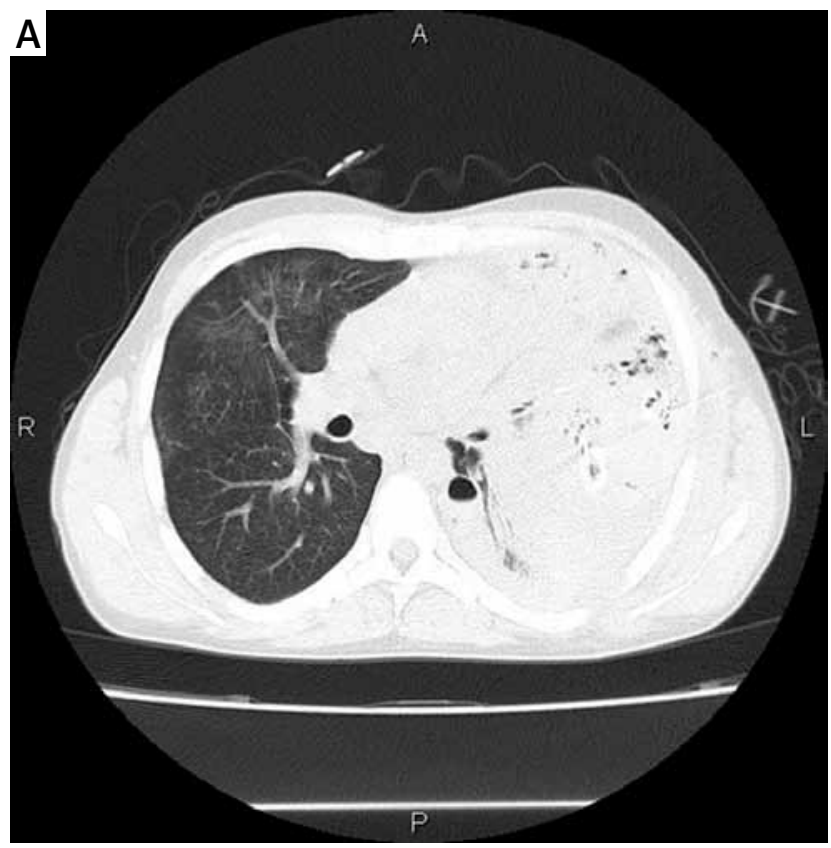

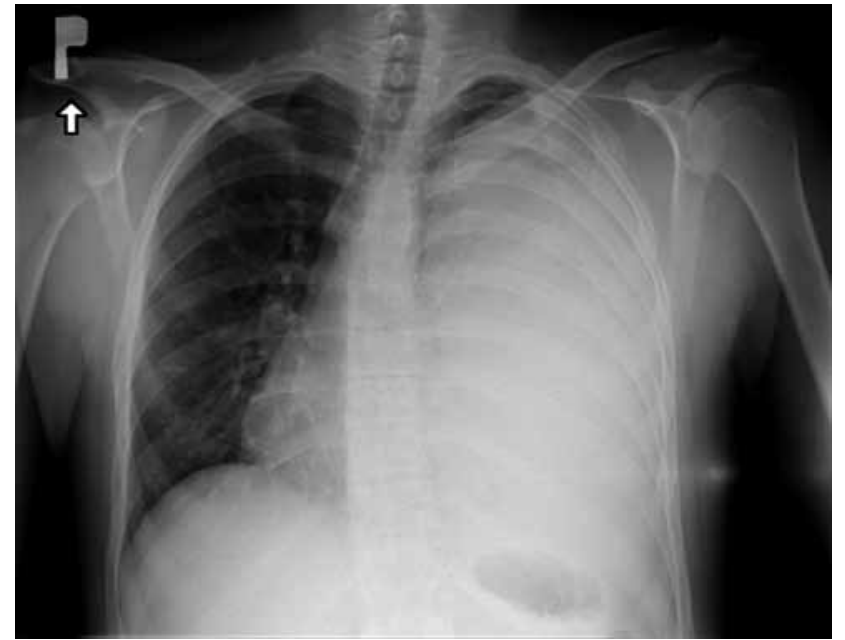

Fig. 1. Follow-up image of the chest after the second aspiration of the left pleural cavity. Large opacity visible in the entire left lung field, mediastinal shift to the right side

field of the left lung, partially in the middle field, as well as in the peripheral sections of the upper field. Chest CT showed massive left-sided pulmonary-pleural lesions, an entirely airless lower left lobe, infiltrative lesions in the majority of the upper left lobe, and pleural fluid collections (Fig. 2). A decision was made to perform left-sided posterolateral rethoracotomy. During the operation, it was revealed that the entire left pleural cavity was filled with thrombi and blood, which were subsequently removed. In the supradiaphragmatic area, the parietal pleura was bleeding from its entire surface; no pinpoint bleeding was found. Additional examination of the supradiaphragmatic area was performed through the $7^{\text {th }}$ intercostal space. Hemostasis was conducted, and two pleural drains were inserted. The patient was transferred from the operating theater directly to the ICU with signs of respiratory failure; mechanical ven-



Fig. 2. Follow-up CT of the chest on the sixth postoperative day. Extensive, massive left-sided pulmonary-pleural lesions. Almost entirely airless lower lobe, enhancing heterogeneously after the use of contrast. Infiltrative lesions in the majority of the upper lobe. Fluid collections visible in the pleural cavity. Two drains inserted into the lesions. Expansion of the right lung without infiltrates 
tilation, antibiotics, steroids, PRBC preparations, and fresh frozen plasma were applied. After three days, the patient was moved to the thoracic surgery department. Laboratory test results after the operation were as follows: Hgb $8.2 \mathrm{~g} \%$, Hct $25 \%$, RBC $2.96 \times 10^{6} / \mu \mathrm{l}$, WBC $22.7 \times 10^{3} / \mu \mathrm{l}$, Plt $372 \times$ $10^{3} / \mu$ l. The patient was transfused with 2 units of PRBC and 2 units of plasma. The amount of drained fluid was $400 \mathrm{ml}$ $+550 \mathrm{ml}$. On the next day, 4 units of PRBC, 2 units of plasma, and recombinant activated factor VII were transfused. It needs to be added that bleeding around the drains occurred on the first day after reoperation and was stopped with the use of hemostatic sutures. On the third postoperative day, the patient started bleeding from the site of the removed arterial line; the hemorrhage was stopped with the use of a pressure dressing, etamsylate, and tranexamic acid. Activated partial thromboplastin time remained at the level of 74-84 seconds, while the daily amount of fluid drained from the left pleural cavity was $100-300 \mathrm{ml}$. In total, the patient received 24 units of PRBC and 19 units of fresh frozen plasma. Coagulopathy was suspected due to the delayed arterial bleeding (4 hours after removal of the catheter from the radial artery). Hematological consultations were performed, and blood samples were taken in order to establish the activity of coagulation factors. The function impairment of one of the factors was suspected to be the cause of the continuous bleeding. The performed tests established the activity of factor VIII at the level of 3.04\% (normal: 70-150\%), factor IX - 76.75\% (normal: 70$120 \%$ ), and factor XII - 29.9\% (normal: $70-150 \%$ ); the presence of antibodies against factor VIII (circulating anticoagulant) was determined qualitatively. The patient was transferred to the hematology department, where he remained in a moderately severe condition with resting inspiratory and expiratory dyspnea, numerous auscultatory changes over the lungs, features of right ventricular heart failure (hepatomegaly, ascites, lower extremity swelling), and renal failure (oliguria). High levels of inflammatory parameters were observed (ESR, CRP), indicating liver damage. Imaging examination confirmed left-sided pneumonia and exudative pericarditis. Factor VIII supplementation, factor VIla (NovoSeven), PRBC (4 units), immunosuppressants (cyclophosphamide and steroids), low-molecular-weight heparin, antibiotics, as well as antihypertensive and antiarrhythmic agents were administered. Gradual improvement of the patient's condition and laboratory parameters was achieved (eradication of the factor VIII inhibitor, normalization of the coagulation system and the parameters of heart and liver function). Pleural drains were removed on the $10^{\text {th }}$ and $14^{\text {th }}$ postoperative days. During the hospitalization, the patient experienced an episode of paroxysmal atrial fibrillation. In order to specify the etiology of the factor inducing the process of autoimmunization, the applied diagnostic methods were supplemented with imaging examinations (CT of the chest, abdominal cavity, and pelvis), digestive tract endoscopy, as well as serological and virological testing. Based on the entire clinical picture, acute interstitial pneumonitis was considered to be the most likely cause of the observed coagulopathy. After being discharged from the hospital, the patient returned to the hematology clinic for a single follow-up examination. He did not attend any subsequent examinations.

\section{Discussion}

Regardless of damage location, massive, sudden, and life-threatening bleeding frequently constitutes an indication for prompt surgical intervention in any patient, even without previous hemostatic disorders in the medical history. Acquired hemophilia is a very rare cause of such bleeding. In the course of this disease, intracranial bleeding as well as bleeding into the digestive tract, genitourinary system, retropharyngeal and retroperitoneal space, pleural cavity, and peritoneal cavity were observed [10, 12-15]. Bleeding into the pleural cavity caused by acquired hemophilia is very uncommon (approx. $1 \%$ of cases), but is usually potentially fatal and may appear after surgical procedures performed within the area of the chest $[3,5,16]$. Bleeding within the area of the chest had been described in women with acquired hemophilia after esophageal resection due to cancer [16]. Other authors reported a hemorrhage into the pleural cavity in one male in a group of 15 acquired hemophilia patients [17]. Such patients may also experience other, less dangerous intramuscular and subcutaneous bleeding, nosebleeds, or bleeding after intravenous punctures and intramuscular injections $[1-5,12,13,18,19]$. According to Forsyth, bleeding into the skin appeared in 53\% of patients [6]. Some authors described bleeding originating from puncture sites and resulting from urinary bladder catheterization [20]. The patient described in this publication exhibited massive, recurrent bleeding into the pleural cavity as well as other, less dangerous bleeding around the inserted pleural drains and from the arterial line removal site. The patient was initially treated with suction drainage of the left pleural cavity and underwent surgery twice later on. Neither the first nor the second operation revealed any pinpoint bleeding; the patient was bleeding from the entire parietal pleura in the supradiaphragmatic area. Both operations were performed via posterolateral thoracotomy. Embolization of the bleeding vessels and videothoracoscopic procedures due to similar indications have also been described [3]. In acquired hemophilia, the bleeding is often recurrent in nature and is very difficult to stop with the use of surgical methods $[16,21]$. With regard to bleeding in different locations, the use of minimally invasive surgical methods, such as laparoscopy in the case of bleeding into the peritoneal cavity, has also been reported. However, these methods may prove to be insufficient for achieving effective hemostasis in the case of extensive bleeding [22]. Other bleeding episodes, occurring in the presented patient, were stopped with the use of pressure dressings and drugs (etamsylate, tranexamic acid). Fresh frozen plasma was also administered, as other authors have done as well. Some authors describe an effective combination therapy with FEIBA (an activated prothrombin complex concentrate) and tranexamic acid [23]. According to the literature, 
the average time between the occurrence of the first signs of a bleeding diathesis to the diagnosis of acquired hemophilia is 1.5 months (from 3 days to 9 months). In the case of the described patient, the disease was diagnosed after about 10 days following the occurrence of the first signs. The suspicion was based on medical history, clinical signs, and prolonged APTT in laboratory tests. Additional examinations confirmed the diagnosis. Significantly reduced activity of factor VIII (3.04\%) and the presence of antibodies against factor VIII with prolonged APTT were also revealed. Some authors report levels of factor VIII activity below $1 \%$ [11]. However, factor VIII activity is not completely eliminated in acquired hemophilia, as opposed to congenital hemophilia. The patient described in the article was diagnosed with hemophilia at the age of 32 . The majority of authors describe much older patients, especially male (60 or older on average), with diagnosed acquired hemophilia [22, 2427]. The mean age of patients registered in EACH2 (the European Acquired Hemophilia Registry) is approx. 77 years; the registry includes 501 people $[24,28]$. The goal of acquired hemophilia therapy is the treatment of coagulation disorders and signs of active coagulopathy, bleeding prevention, and antibody eradication [4, 9]. In certain cases, persistent anemia caused by recurrent massive or smaller bleeding may require the transfusion of large amounts of PRBC. The described patient received 24 units of PRBC and 19 units of fresh frozen plasma in total before the cause of the bleeding was found. Some patients have required the postoperative transfusion of over 20 units of PRBC and 15 units of fresh frozen plasma before acquired hemophilia was diagnosed [2, 16, 22]. The described patient received recombinant factor VII a. Such treatment is also mentioned by other authors $[2-4,5,9,12]$. The use of recombinant factor VII a or an activated prothrombin complex concentrate (FEIBA) constitutes first-line therapy in acquired hemophilia $[4,13-15,23,26,29,30]$.

Oral glucocorticosteroids (GCS), e.g. prednisone alone or combined with cytotoxic drugs, mainly cyclophosphamide, are typically used for eradication treatment [1, 2, 4, 9, 31]. In the presence of contraindications, rituximab (Mabthera) or, in certain cases, other cytotoxic and immunosuppressive drugs, such as azathioprine, vincristine, mycophenolate, or cyclosporine, are administered [4, 6, 32].

It was observed that spontaneous remission of acquired hemophilia may occur at different times after diagnosis $[1,26]$. Spontaneous elimination of antibodies against factor VIII is estimated at about $14-35 \%$ within a period of time lasting from 3 weeks to 18 months, or even several years $[13,17,26]$.

There are reports of extensive, elective surgical and orthopedic procedures performed without any significant hemorrhagic complications in patients with acquired hemophilia; their success was dependent on appropriate perioperative conduct $[26,29]$.

On the basis of the presented case, an analysis of the literature concerning acquired hemophilia from the last 10 years was performed with special attention to surgical treatment and bleeding in the area of the chest during the course of the disease. Selected studies are helpful in comprehensively illustrating the issue of acquired hemophilia in the context of the described case.

The literature includes an analysis of the causes of death of 121 patients with acquired hemophilia within 10 years in France. The mean age of these patients was 80.7 years (ranging from 47 to 99 ). The main cause of death was hemorrhagic shock (52.9\%); the source of bleeding could not be specifically established in $75 \%$ of patients [10]. Other authors analyzed the cases of acquired hemophilia in the United Kingdom in the years 2001-2003. The mean age of the patients was 78 years, with men constituting $43 \%$ of this group. The most commonly observed type of bleeding was bleeding into the hypodermis. The mortality rate resulting from bleeding was approx. 9.1\%. GCS or GCS combined with cyclophosphamide was used in the eradication treatment [1]. Another publication described a group of 13 patients (females) treated in the years 1999-2011 in a single center. The mean age of the entire group was 60.6 years (from 28 to 84). Six individuals were over 70 . These patients suffered from bleeding into the hypodermis and muscles as well as postoperative bleeding, often recurring multiple times. In this group, none of the hemorrhages resulted in death. The reasons for delayed diagnosis were also analyzed, with emphasis put on the diagnostic difficulties associated with this rare disease. The establishment of a correct diagnosis required 1.5 months on average (from 3 days to 9 months). Severe bleeding was treated with FEIBA or recombinant activated factor VII. The eradication treatment employed the so-called Budapest protocol or a modified VAD protocol [2]. Other authors described 10 cases of acquired hemophilia diagnosed in the years 1988-1997 in patients aged 28-76, who experienced such signs of hemostasis disorders as petechiae, subcutaneous hematomas, and intramuscular hemorrhages (in approx. $60 \%$ ). No bleeding in the area of the chest organs was observed [11]. German authors presented a group of 67 patients treated in the years 1998-2008 in a single center. The group consisted of individuals at the mean age of 62 years and included 50 women. All patients experienced bleeding into the muscles; other hemorrhages included bleeding into the extraperitoneal space (16 patients), bleeding into the retropharyngeal space (5 patients), hematuria (3 patients), and bleeding into the digestive tract ( 1 patient). Five patients died in total, four of them after surgical procedures. In 27 individuals, recombinant activated factor VII was used in the initial treatment. Patients with severe, life-threatening bleeding were treated using the so-called modified BonnMalmo protocol [33]. Moreover, 3 cases of acquired hemophilia diagnosed in the years 2003-2006 have also been described. The first of these patients was a 51-year-old man who underwent a decompression of the fascial compartments due to a massive, post-traumatic hematoma of the arm. The procedure was followed by massive bleeding, which resulted in hemorrhagic shock. Hematomas on both legs appeared in another 68-year-old patient treated with 
warfarin and suffering from bronchial asthma, atrial fibrillation, and a complex heart-valve disorder. The third patient, a 66-year-old man with acute bronchial asthma, suffered from spontaneously appearing hematomas on both lower extremities [18]. Other authors described a case of an 82-year-old man with post-traumatic bleeding into the retroperitoneal space. After exploratory laparotomy, the patient experienced surgical site bleeding, which was difficult to stop. Testing revealed acquired hemophilia. No pinpoint bleeding was found during the exploratory laparotomy nor during further examinations [12]. Another work describes a case of a 26-year-old woman with a large, spontaneous hematoma in the thigh muscles. Acquired hemophilia was suspected based on the clinical picture and prolonged APTT. The applied treatment resulted in remission. The authors of the study emphasize the importance of prompt diagnosis and treatment of this disease [13].

It needs to be emphasized that acquired hemophilia always has to be taken into consideration in the presence of sudden bleeding into the skin, mucous membranes, or body cavities (in congenital hemophilia - delayed hemorrhages into the muscles or joints, mostly in males) when prolonged APTT is the only abnormality in the coagulation system [34]. In such cases, it is crucial to detect the factor VIII inhibitor: perform a normal plasma mixing study and establish APTT, and establish the titer of the antibodies against factor VIII with the Bethesda test. The titer of the antibodies against factor VIII and the level of factor VIII do not correspond to the severity of the diathesis. It is essential to begin a dual treatment consisting in the eradication of the antibodies and the administration of factors bypassing the hemostatic defect.

\section{Disclosure}

The authors report no conflict of interest.

\section{References}

1. Collins PW, Hirsch S, Baglin TP, Dolan G, Hanley J, Makris M, Keeling DM, Liesner R, Brown SA, Hay CRM. Aquired hemophilia A in the United Kingdom: a 2-year national surveilance study by the United Kingdom Haemophilia Centre Doctors' Organisation. Blood 2007; 109: 1870-1877.

2. Arokszallasi A, Ilonczai P, Razso K, Olah Z, Bereczky Z, Boda Z, Schlammadinger A. Acquired haemophilia: an often overlooked cause of bleedingexperience from a Hungarian tertiary care centre. Blood Coagul Fibrinolysis 2012; 23: 584-589.

3. Fukushima T, Mikane T, Ono D, Oku S, Kobayashi H, Watanabe Y, Iwasaki E, Ishii M, Tokioka H. A case of acquired hemophilia A with massive hemothorax. J Anesth 2012; 26: 262-264.

4. Huth-Kuhne A, Baudo F, Collins P, Ingerslev J, Kessler CM, Lévesque H, Castellano ME, Shima M, St-Louis J. International recommendations on the diagnosis and treatment of patients with acquired hemophilia A. Haematologica 2009; 94: 566-575.

5. Baudo F, De Cataldo F. Acquired hemophilia: a critical bleeding syndrome. Haematologica 2004; 89: 96-100.

6. Forsyth AL, Giangrande P, Hay CRM, Kenet G, Kessler CM, Knobl PN, Llinas A, Santagostino E, Young G. Difficult clinical challenges in haemophilia: international experimental perspectives. Haemophilia 2012; 18 (Suppl. 5): 39-45.

7. Laselle BT, Boggio LN, Blum MG. Presentation and management of a stage ia lung cancer patient with a paraneoplastic factor viii inhibitor. Ann Thorac Surg 2006; 81: 362-364.
8. Franchini M, Gandini G, Di Paolantonio T, Mariani G. Acquired hemophilia A: a concise review. Am J Hematol 2005; 80: 55-63.

9. Buczma A, Windyga J. Acquired haemophilia. Pol Arch Med Wewn 2007; 117: 241-245.

10. Aouba A, Rey G, Pavillon G, Jougla E, Rotschild C, Torchet MF. Deaths associated with acquired haemophilia in France from 2000 to 2009: multiple cause analysis for best care strategies. Haemophilia 2012; 18: 339-344.

11. Saxena R, Mishra DK, Kashyap R, Choudhry VP, Mahaparta M, Bhargava M. Acquired haemophilia - a study of ten cases. Haemophilia 2000; 6: 78-83.

12. Cortegiani A, Russotto V, Foresta G, Montalto F, Strano MT, Raineri SM, Giarratano A. A perioperative uncontrollable bleeding in an elderly patient with acquired hemophilia A: a case report. Clin Case Rep 2013; 1: 3-6.

13. Kang E, Kim HG, Lee J, Lee M, Bae C, Jeon JY, Ahn MS, Jeong SH, Park JS, Kang SY, Choi J-H, Lee HW. Acquired hemophilia successfully treated with activated prothrombin complex concentrate and immunosupresant combination: a case report. Blood Coag Fibrinol 2012; 23: 669-672.

14. Holme PA, Brosstad F, Tjonnfjord GE. Acquired haemophilia: management of bleeds and immune therapy to eradicate autoantibodies. Haemophilia 2005; 11: 510-515.

15. Sumner MJ, Geldziler BD, Pedersen M, Seremetis S. Treatment of acquired haemophilia with recombinant activated FVII: a critical appraisal. Haemophilia 2007; 13: 451-461.

16. Hosoya Y, Matsumura M, Madoiwa S, Zuiki T, Matsumoto S, Nunomiya S, Lefor A, Sata N, Yasuda Y. Acquired hemophilia A caused by factor VIII inhibitors: report of a case. Surg Today 2013; 43: 670-674.

17. Huang YW, Saidi P, Philipp C. Acquired factor VIII inhibitors in non-haemophilic patients: clinical experience of 15 cases. Haemophilia 2004; 10: 713-721.

18. del Campo R, Bargay J, Cladera A, Balaguer H, Requena MJ, Mascaro M. Acquired hemophilia A: three different presentations of the same disease. Blood Coag Fibrinol 2010; 21: 188-191.

19. Wysocka A, Kudela A. Hemofilia nabyta - Acquired haemophilia (AH). Hemostaza Express 2009; 8: 1-4.

20. Delgado J. Acquired haemophilia: review and meta-analysis focused on therapy and prognostic factors. Brit J Haemat 2003; 121: 21-35.

21. Lauer S, Westphal M, Fischer LG, Meissner A, Van Aken H, Freise H. Recombinant factor VIla and factor VIII treatment for acquired factor VIII deficiency: a case of repeated thrombotic endotraheal occlusion in a mechanically ventilated patient. Crit Care 2011; 15: 407.

22. Johansen RF, Sorensen B, Ingerslev J. Acquired haemophilia: dynamic whole blood coagulation utilized to guide haemostatic therapy. Haemophilia 2006; 12: 190-197.

23. Holmstrom M, Tran HTT, Holme PA. Combined treatment with APCC (FEIBA) and tranexamic acid in patients with haemophilia $A$ with inhibitors and in patients with acquired haemophilia A - a two-centre experirnce. Haemophilia 2012; 18: 544-549.

24. Collins P, Baudo F, Knoebl P, Levesque H, Nemes L, Pellegrini F, Marco P, Tengborn L, Huth-Kuhne A. Immunosupression for acquired hemophilia A: results from the European Acquired Haemophilia Registry (EACH2). Blood 2012; 120: 47-55.

25. Negrier C, Lienhart A, Numerof R, Stephens D, Wong WY, Baghaei F, Yee TT. Surgical interventions with FEIBA (SURF): international registry of surgery in haemophilia patients with inhibitory antibodies. Haemophilia 2013; 19: e143-e150.

26. Onishi I, Kayahara M, Munemoto M, Sakai S, Makino I, Hayashi H, Nakagawara H, Tajima H, Takamura H, Kitagawa H, Tani T, Ohta T. Management of postoperative hemorrhage associated with factor VIII inhibitor: report of a case. Surg Today 2013; 43: 1058-1061.

27. Notarnicola A, Pesce V, Scaraggi A, Maccagnano G, Vicenti G, Moretti B. Total hip replacement in a patient with acquired haemophilia a: a case report and literature review. Blood Coagul Fibrinol 2011; 22: 436-439.

28. Knoebl P, Marco P, Baudo F, Collins P, Huth-Kuhne A, Nemes L, Pellegrini F, Tengborn L, Levesque $\mathrm{H}$. Demographic and clinical data in acquired hemophilia A: results from the European Acquired Haemophilia Registry (EACH2). J Thromb Haemost 2012; 10: 622-631.

29. Rangarajan S, Yee TT, Wilde J. Experience of four UK comprehensive care centers using FEIBA for surgeries in patients with inhibitors. Haemophilia 2011; 17: 28-34.

30. Sallah S. Treatment of acquired haemophilia with factor eight inhibitor bypassing activity. Haemophilia 2004; 10: 1690173. 
31. Sokołowska B, Walter-Croneck A, Gromek T, Dmoszyńska A. Hemofilia nabyta i zagrażające życiu krwawienia - trudny problem kliniczny dotyczący nie tylko mężczyzn, ale również kobiet. Acta Haematol Pol 2011; 42: 583-591.

32. Sperr WR, Lechner K, Pabinger I. Rituximab for the treatment of acquired antibodies to factor VIII. Haematologica 2007; 92: 66-71.

33. Zeitler H, Ulrich-Merzenich G, Goldmann G, Vidovic N, Brackmann HH, Oldenburg J. The relevance of the bleeding severity in the treatment of acquired haemophilia - an update of a single-centre experience with 67 patients. Haemophilia 2010; 16: 95-101.

34. Ichikawa S, Kohata K, Okitsu Y, Suzuki M, Nakajima S, Yamada MF, Onishi Y, Yamamoto J, Suzuki S, Ishizawa K, Kameoka J, Harigae H. Acquired hemophilia A with sigmoid colon cancer: successful treatment with rituximab followed by sigmoidectomy. Int J Hematol 2009; 90: 33-36. 